\title{
Psicooncología
}

ISSN: 1696-7240

\section{Relationship between doctors and patients in the end of life process in palliative care and dysthanasia}

\author{
Cynthia de Freitas Melo ${ }^{1 *}$; Maria Rannielly de Araujo Lima Magalhães ${ }^{2}$; Liza Maria Studart \\ de Meneses ${ }^{3}$; Railda Sabino Fernandes Alves ${ }^{4}$; Ana Cristina Eberhardt Lins ${ }^{5}$; Elisa Kern de \\ Castro $^{6}$
}

Recibido: 30 de septiembre de 2020 / Aceptado: 1 de marzo de 2021

\begin{abstract}
Introduction: In the course of an illness, when the patient receives a poor prognosis, he can be assisted with dysthanasia or palliative care. The therapeutic choice and the adherence to it are related, among other factors, to the quality of the doctor-patient relationship. The objective of this study was to evaluate the patients' point of view of the doctor-patient relationship in the end of life process, and compare scores between patients in palliative care and those experiencing dysthanasia.

Method: The design was a descriptive survey with a non-probabilistic sample composed of 234 patients with cancer in the end of life process: 117 in palliative care and 117 expriencing dysthanasia. Two instruments were used: a biodemographic questionnaire and the Questionnaire for Assessing the DoctorPatient Relationship in the End of Life Process, and data were analyzed using descriptive and bivariate statistics in the Statistical Package for the Social Sciences software. Results: The results showed good evaluations of the doctor-patient relationship. Palliative care patients attributed better scores in terms of time dedicated, attention, confidence, understanding and communication; and patients experiencing dysthanasia made better assessments in terms of frequency of visits and continuity of care. Conclusion: It is concluded that this study represents an advance in studies on the subject and indicates that patients in palliative care perceive the doctor-patient relationship more positively than patients undergoing dysthanasia. It stressed that it is necessary to invest in training medical students and professionals to carry out interventions that prioritize the use of their oldest, simplest and most powerful technology: the relationship between professionals and patients.
\end{abstract}

Keywords: Doctor-patient relationship, palliative care, dysthanasia, medical oncology, death.

1 Cynthia de Freitas Melo. Graduate Program in Psychology, University of Fortaleza, Ceará, Brazil.

E-mail: cf.melo@yahoo.com.br

2 Maria Rannielly de Araujo Lima Magalhães. Graduate Program in Psychology, University of Fortaleza, Ceará, Brazil.

E-mail: rannymagalhaes@hotmail.com

3 Liza Maria Studart de Meneses. Undergraduate Program in Psychology, University of Fortaleza, Ceará, Brazil. E-mail: lizastudart1@gmail.com

4 Railda Sabino Fernandes Alves. Graduate Program in Health Psychology, State University of Paraíba, Paraíba, Brazil.

Email: raildafernandesalves@gmail.com

5 Ana Cristina Eberhardt Lins. Abel Salazar Institute of Biomedical Sciences, University of Porto, Porto, Portugal Email: anacristinae@gmail.com

6 Elisa Kern de Castro. Lusíada University of Lisbon, Lisbon, Portugal

Email: elisa.kerndecastro@gmail.com

* Dirección de correspondencia: Cynthia Melo. Av. Washington Soares, 1321, Sala E01. Bairro Edson Queiroz, CEP.60.811-341. Fortaleza-CE, Brazil. E-mail: cf.melo@yahoo.com.br 


\section{[es] Relación entre médicos y pacientes en proceso en el final de la vida en cuidados paliativos y distanasia}

Resumen: Objetivo: En el curso de una enfermedad, cuando el paciente recibe un pronóstico reservado, puede ser asistido con distanasia o con cuidados paliativos. La elección terapéutica y la adherencia están relacionadas, entre otros factores, con la calidad de la relación médico-paciente. El objetivo fue evaluar, desde el punto de vista de los pacientes, la relación médico-paciente en el proceso de finitud, y comparar sus índices entre pacientes en cuidados paliativos y en distanasia.

Método: El diseño es descriptivo y encuesta, y tuvo una muestra no probabilística compuesta por 234 pacientes con cáncer en proceso de finitud: 117 en cuidados paliativos y 117 en distanasia. Se utilizaron dos instrumentos, un cuestionario biodemográfico y un cuestionario para la evaluación de la relación médico-paciente, cuyos datos fueron analizados mediante estadística descriptiva y bivariada en el software Statistical Package for the Social Sciences. Resultados: Los resultados mostraron que los pacientes tuvieron buenas evaluaciones de la relación médico-paciente. Los pacientes de cuidados paliativos tuvieron mejores índices en términos de tiempo dedicado, atención, confianza, comprensión y comunicación; y los pacientes en distanasia evaluaron mejor la frecuencia de las visitas y la continuidad de la atención. Conclusión: Se concluye que el estudio representa un avance en los estudios sobre el tema e indica que los pacientes en cuidados paliativos perciben la relación médico-paciente de manera más positiva que los pacientes en distanasia. Se refuerza la necesidad de invertir en la formación de estudiantes y profesionales de medicina para llevar a cabo intervenciones que prioricen el uso de su tecnología más antigua, sencilla y poderosa: la relación entre profesionales y pacientes.

Palabras clave: Relación médico-paciente, cuidados paliativos, distanasia, oncología, muerte.

Sumario: 1. Introduction 2. Method 3. Data analysis procedures 3. Results 4. Discussion 5. Conclusions. 6. References

Cómo citar: de Freitas Melo C, de Araujo Lima Magalhães MR, Studart de Meneses LM, Sabino Fernandes Alves R, Eberhardt Lins AC, Kern de Castro E. Relationship between doctors and patients in the end of life process in palliative care and dysthanasia. Psicooncología 2021; 18; 193-205. doi: $10.5209 /$ psic.74539

\section{Introduction}

Technological and scientific advances in the field of diagnosis and treatment of diseases have had a strong impact on the practices of health professionals, in especial of physicians. These advances have been responsible, among other things, for increasing people's life expectancy ${ }^{(1)}$. In an ambivalent manner, the overlapping of hard technologies (equipment and complex materials developed by man) over light ones (concerning relationships, for the production of embracement, communication, bonds and autonomy $)^{(2)}$ has caused profound changes in the relationship between professionals and their patients, which is currently characterized by difficulties in both sides of the dyad ${ }^{(3)}$. The use of biotechnologies together with a high demand for care has reflected in a decrease of physical contact, time for consultations, and comprehensive approach when dealing with the sick person, including a look that goes beyond his/her illness and medical exams. These factors influence the assessment of the quality of the service provided ${ }^{(4)}$.

In clinics and hospitals, the dominant model of relationship between health professionals (including doctors) and their patients is still the one in which the professional is considered the holder of knowledge ${ }^{(5-6)}$ and those who seek help are 
considered subordinate to medical practice ${ }^{(7)}$, opposite to the biopsychosocial model of health care ${ }^{(8)}$. The doctor usually indicates the most appropriate treatment and the medicines to be used, as well as how the patient can best deal with his/her illness. The doctor also suggests what can be good or bad for the individual, considering the illness, sometimes without valuing the peculiarities, subjectivity, autonomy and experience of the sick subject. The sick person often prevails over the subject who has the disease and, in general, accepts and shows submission to the sovereignty of the knowledge of the professional. The patient has limited autonomy and freedom of decision before medical knowledge. There is no sharing of information, experiences and joint decisions ${ }^{(9)}$, as opposed to the proposal for shared decision making ${ }^{(10)}$.

In the case of patients with a poor prognosis, the sovereignty of knowledge and medical power, when associated with the desire of health professionals, patients and their families to tirelessly fight against death and prolong a person's life at any cost has several implications for the life of the sick person ${ }^{(11)}$. The illusion that the patient will be saved at all costs can interfere and cause a negative impact on the way he/ she will die ${ }^{(12)}$, leading to a process called dysthanasia. Dysthanasia refers to the practice that makes excessive use of therapeutic procedures in order to prolong the life of a person who has no possibility of cure ${ }^{(13)}$. However, the process of death and suffering is prolonged, not life. In this context, denial of death can generate even more suffering for this patient and the family that assists him $^{(14)}$.

In view of the need to alleviate the suffering of the dying individual and his family, and to offer greater quality in health services, the relationship between doctor, patient and family started to be analyzed as one of the conditions to break the "taboo" and enhance the acceptance of death by all involved in this triad"(15), facilitating the adherence of care therapy ${ }^{(16)}$. To this end, a "meeting" between the two subjects is necessary, seeking an intersection between the practices and technologies adopted by the health care provider and the patient's health needs, experiences and expectations ${ }^{(17)}$, whose result is unpredictable and unique.

To achieve this, the sick individual must be understood in his entirety and uniqueness. Not only his biological body, but the whole processes that he may experience $^{(9,14,18)}$, his total pain - physical, psychological, social and spiritual - must be taken into account ${ }^{(19)}$. His family must also receive attention, be embraced and cared for in the suffering experienced ${ }^{(20)}$.

In this biopsychosocial care model, health professionals are urged to offer freedom and autonomy to the sick subject, so that he can be respected in his subjectivity. The patients' empowerment and participation in their health-disease process are encouraged, even in the case of patients with a poor prognosis ${ }^{(15,16)}$. This does not mean that the professional is not responsible for his actions, but it does give the patient the possibility to choose his treatment, as well as to choose what will be done with his own body. This will result in a better quality of life in the death process. To achieve this shared decision, it is important to higlight the duty of the physician to inform the patient about his health condition, diagnosis, prognosis and indicated treatment ${ }^{(5)}$.

Within this proposal of respect for the individual's life and uniqueness, palliative care emerges as an approach that improves the quality of life of patients and families who face problems related to life-threatening diseases, by means of prevention and relief of suffering through early identification and impeccable assessment and treatment of pain and other physical, psychosocial and spiritual problems ${ }^{(21,22)}$. Through the action of an interdisciplinary team, the objectives of palliative care are: to provide relief from 
pain and other distressing symptoms; affirm life and regard dying as a normal process; neither to hasten or postpone death; integrate the psychological and spiritual aspects of patient care through an interdisciplinary team; offer a support system to help patients live as actively as possible until death; offer a support system to help the family cope during the patient's illness and in their own bereavement; and enhance quality of life, and also positively influence the course of illness ${ }^{(21,23)}$.

Palliative care is not restricted to patients in the end of life process. It is applicable early in the course of the disease, since its diagnosis, in conjunction with other therapies aimed at prolonging life, such as chemotherapy or radiation therapy in cancer patients, and includes the investigations necessary to better understand and manage distressing clinical complications ${ }^{(21,22,24)}$. These measures are concomitant to the curative approach only as the illness progresses, when/if the patient has no more prognosis of cure and the procedures no longer have this goal, but rather aim to reduce symptoms or improve the quality of life ${ }^{(21)}$.

Among patients with a life-threatening disease, those with chronic-degenerative diseases, mainly cardiovascular diseases and cancer, prevail ${ }^{(25)}$. Cancer is a serious and stigmatized disease, characterized by suffering, fear of death and uncertainties in its entire process, since diagnosis and throughout treatment. These aspects make communication a fundamental tool, and the relationship between the patient and health professionals has to be necessarily thoughtful and fundamentally empathetic, always aiming to care for this subject ${ }^{(15)}$.

Palliative care is a challenging task for many physicians ${ }^{(26)}$, for fear of the patient's reaction, for fear of approaching the patient who is going through severe distress, for lack of training and skills for this contact, for fear of complaints or lawsuits and/or lack of knowledge about several techniques and protocols that help professionals to communicate bad news ${ }^{(27)}$. Therefore, the palliative care approach requires a change in medical training, with education for death, in Thanatology ${ }^{(1)}$, and with greater investments in light technologies ${ }^{(2)}$, following national and international guidelines that advise the teaching of communicative and relationship skills in medical schools ${ }^{(16)}$.

Based on the above, it is recognized that, if the disease progresses and the patient receives a reserved prognosis, with no possibility of cure, at least two paths are possible: death can be denied, and therapeutic obstinacy (dysthanasia) maintained; or death can be recognized, and with the aid of palliative care, dignity in dying can be offered. The therapy chosen and the adherence may be associated, in addition to other factors, to the quality of the relationship between patient and doctor, promoting the establishment of a bond of safety and certainty of care ${ }^{(9,27)}$.

This is a difficult topic of research, especially from the approach to patients, which is why still a small number of studies have analyzed the process of dying from the perspective of those who are in their last days of life. However, it is necessary to speak of the unspeakable and break the silence. With ethical and moral care, it is possible to research the phenomena involved in the dying process, identifying the possibilities of care, even the possibility of cure does not exist ${ }^{(25)}$.

It is also important to carry out studies in hospitals in the Brazilian Unified Health System (SUS) in Brazil so as to offer scientific evidence on simple and low-cost technologies to respond to the demand for scientifically based practices that show effectiveness, efficiency and replicability ${ }^{(28)}$. To this end, this study had the objective to give voice to patients, as they are a powerful source of information about the everyday reality of the services that are provided in public hospitals during the 
dying process ${ }^{(29)}$. In this sense, the present study aimed to assess the doctor-patient relationship in the end of life process, from the patients' point of view, and compare its indices between patients in palliative care and in dysthanasia.

\section{Method}

\section{Design}

This is an ecological study, of the survey type, with a quantitative and cross-sectional approach.

\section{Sample}

A non-probabilistic sample composed of 234 patients with cancer in the process of end of life assisted at five public hospitals in Ceará, by SUS, was divided into two groups: palliative care (Group 1) with 117 patients, and dysthanasia (Group 2) with 117 patients. The decision to limit the study to cancer patients was due to the need to avoid that the type of disease generated bias in the data.

As inclusion criteria, the following were considered: 1) Group 1 - adult patients with a reserved prognosis declared in medical records and followed up by the palliative care service (in hospital or home care); 2) Group 2 - adult patients who had a prognosis of end of life, metastasis or whose treatments no longer had a curative effect (characteristics of patients indicated for complementary or exclusive palliative care), but not yet palliated, undergoing curative treatments, in dysthanasia, hospitalized at the hospital. For stratification, the status performance of patients was considered.

The average age of the participants was 60.42 years $(\mathrm{SD}=14.76)$, varying from 19 to 92 years. There was a prevalence of patients of the female sex $(f=131 ; 56.00 \%)$; married $(f=129 ; 55.10 \%)$; without complete elementary school $(f=76 ; 32.50 \%)$, Catholic $(f=167 ; 40.00 \%)$, who were not employed $(f=184 ; 78.60 \%)$, who had a support network $(f=220 ; 94.00 \%)$ and had no leisure activities $(f=162 ; 69.20 \%)$. Table 1 shows the participantss' biodemographic data, distributed in both groups.

Table 1. Distribution of participants by biodemographic data

\begin{tabular}{lcccc} 
& Variable & \multicolumn{2}{c}{$\begin{array}{c}\text { Patients experiencing } \\
\text { dysthanasia }\end{array}$} & \multicolumn{2}{c}{$\begin{array}{c}\text { Patients experiencing } \\
\text { palliative care }\end{array}$} \\
\cline { 2 - 5 } Sex & Frequency & Percentage & Frequency & Percentage \\
\hline Female & 62 & 53.0 & 69 & 59.0 \\
Male & 55 & 47.0 & 48 & 41.0
\end{tabular}

\section{Marital status}

Single 


\begin{tabular}{|c|c|c|c|c|}
\hline \multirow{2}{*}{ Sex } & \multicolumn{2}{|c|}{$\begin{array}{l}\text { Patients experiencing } \\
\text { dysthanasia }\end{array}$} & \multicolumn{2}{|c|}{$\begin{array}{l}\text { Patients experiencing } \\
\text { palliative care }\end{array}$} \\
\hline & Frequency & Percentage & Frequency & Percentage \\
\hline Married & 67 & 57.8 & 62 & 56.9 \\
\hline Divorced & 12 & 10.3 & 08 & 7.3 \\
\hline Widowed & 20 & 17.2 & 17 & 15.6 \\
\hline \multicolumn{5}{|l|}{ Education } \\
\hline Incomplete primary school & 40 & 35.1 & 36 & 33.6 \\
\hline Complete primary school & 02 & 1.8 & 04 & 3.7 \\
\hline Incomplete secondary school & 35 & 30.7 & 40 & 37.4 \\
\hline Complete secondary school & 27 & 23.7 & 24 & 22.4 \\
\hline Incomplete Higher Education & 02 & 1.8 & 00 & 0.0 \\
\hline Complete Higher Education & 05 & 4.4 & 01 & 0.9 \\
\hline No schooling & 03 & 2.6 & 02 & 1.9 \\
\hline \multicolumn{5}{|l|}{ Religion } \\
\hline Catholicism & 81 & 73.6 & 86 & 75.4 \\
\hline Evangelical & 26 & 23.6 & 25 & 21.9 \\
\hline Others & 03 & 2.7 & 03 & 2.6 \\
\hline \multicolumn{5}{|l|}{ Work } \\
\hline Yes & 27 & 23.7 & 17 & 14.9 \\
\hline No & 87 & 76.3 & 97 & 85.1 \\
\hline \multicolumn{5}{|l|}{ Support network } \\
\hline Yes & 109 & 93.2 & 111 & 95.7 \\
\hline No & 08 & 6.8 & 05 & 4.3 \\
\hline \multicolumn{5}{|l|}{ Leisure activity } \\
\hline Yes & 49 & 43.0 & 18 & 15.7 \\
\hline No & 65 & 57.0 & 97 & 84.3 \\
\hline
\end{tabular}

* Valid percentages were considered, missing responses were disregarded 


\section{Instruments}

A questionnaire called Questionnaire for Assessing the Doctor-Patient Relationship in the End of Life Process, based on the Patient-Doctor Relationship Questionnaire (PDRQ-9) $)^{(30)}$, was created to assess the doctor-patient relationship. The new questionnaire consists of 7 items that assess different aspects of the patient-doctor relationship, namely, attention, time, availability, understanding, dedication, trust and communication of doctors. They are organized in a single factor, which explains $47.80 \%$ of the total variance of the studied construct, has a good internal consistency according to the Cronbach's alpha $(\alpha=0.77)$ index and has dichotomous responses (Yes/No). A sociodemographic questionnaire covering information on sex, age, education, marital status, religion, work, income, support network, leisure, and information on hospital care, illness and treatments performed, was also used.

\section{Data collection procedures}

Data were collected in five public hospitals in Ceará by researchers who are health professionals with/without job bond with the research locus. Before data collection, a selection of patients was made to check the inclusion criteria, through the analysis of their medical records and collection of additional information with the professionals of the interdisciplinary care team that followed up the patients. Then, the patients were visited in hospitals (wards and chemotherapy sector) or at home to be invited to participate in the research and for application of the instruments. In these unique meetings, in the form of dialogue and respecting the moment, desire and physical limitation of the patients, the information was collected; the conversation lasted 60 minutes on average.

\section{Data analysis procedures}

The data were analyzed using descriptive statistics and sample comparisons with the aid of the Statistical Package for the Social Sciences (SPSS) version 25, in three stages. First, the profile of the sample was analyzed using descriptive statistics (frequency, percentage and measures of central tendency and dispersion). Then, to present the general results regarding the assessment of the quality of the doctorpatient relationship, the number of positive responses in each item of the instrument was verified using descriptive statistics. For interpretation, items with more than $50 \%$ of approval by the participants were considered a "positive evaluation".

The means of the responses of the evaluations of the doctor-patient relationship between different groups were compared according to clinical and sociodemographic data. First, a comparison was made of the number of people who positively evaluated each item of the instrument according to the type of care (palliative $\mathrm{x}$ dysthanasia) using the Chi-square test. This allowed detecting differences in the number of patients in each type of care that positively evaluated the relationship with their doctors.

Next, the sum of points for each subject, which varied from 0 to 7 points (where the higher the value, the better the assessment), based on all clinical and sociodemographic variables, was compared. As this score presented a non-normal distribution, according to results of the Shapiro-Wilk test $(W=0.49 ; p<0.001)$, the non-parametric Mann-Whitney U test and Kruskal-Wallis test were used. 


\section{Ethical aspects of the research}

The project was approved by the Research Ethics Committee under opinion $\mathrm{n}^{\circ}$ $2,428,047$ and the research was carried out in accordance with ethical standards, respecting Resolutions 466/12, 510/16 and 580/18 of the National Health Council and with the due informed consent of the participants.

\section{Results}

This study evaluated different aspects of the doctor-patient relationship: attention, time, availability, understanding, dedication, trust and communication with physicians. The results showed that the majority of participants evaluated the relationship with the doctors who followed them in their dying process as positive (see Table 2).

Table 2. Evaluation of the doctor-patient relationship performed by the total sample

\begin{tabular}{lcccc}
\hline \multirow{2}{*}{ Item } & \multicolumn{2}{c}{ Yes } & \multicolumn{2}{c}{ No } \\
\cline { 2 - 5 } & $f$ & $\%$ & $f$ & $\%$ \\
\hline Does my doctor visit me often? & 199 & 85.00 & 35 & 15.00 \\
Does my doctor have enough time for me? & 199 & 85.00 & 35 & 15.00 \\
Is the doctor attentive to me? & 223 & 95.30 & 11 & 4.70 \\
Do I trust my doctor? & 228 & 97.40 & 6 & 2.60 \\
Does my doctor understand me? & 228 & 97.40 & 6 & 2.60 \\
Does my doctor continue taking care of me? & 231 & 98.70 & 3 & 1.30 \\
Am I satisfied with the communication with my doctor? & 223 & 95.30 & 11 & 4.70 \\
\hline
\end{tabular}

In the end, comparisons of the evaluation scores of the doctor-patient relationship were made to verify if there was a difference between the two groups, that is, between patients in palliative care and those experiencing dysthanasia. The results indicated a statistically significant difference in all items of the doctorpatient relationship. In two items, patients experiencing dysthanasia had a higher percentage of positive evaluations, namely, frequency of visits and continuation of care. In the other five items, positive evaluations predominated among patients in palliative care (Table 3). 
Table 3. Comparison of evaluations of the doctor-patient relationship between patients in palliative care and experiencing dysthanasia

\begin{tabular}{|c|c|c|c|}
\hline Item & $\begin{array}{l}\text { Positive evaluation of } \\
\text { patients experiencing } \\
\text { dysthanasia }\end{array}$ & $\begin{array}{c}\text { Positive evaluation } \\
\text { of Patients in } \\
\text { palliative care }\end{array}$ & Chi-square \\
\hline Does my doctor visit me often? & $f=107 ; 91.50 \%$ & $f=91 ; 77.80 \%$ & {$\left[x^{2}(2)=8.40 ; p<0.05\right]$} \\
\hline $\begin{array}{l}\text { Does my doctor have enough } \\
\text { time for me? }\end{array}$ & $f=93 ; 79.50 \%$ & $f=106 ; 90.60 \%$ & {$\left[x^{2}(2)=5.68 ; p<0.05\right]$} \\
\hline Is the doctor attentive to me? & $f=106 ; 90.60 \%$ & $f=114 ; 97.40 \%$ & {$\left[x^{2}(2)=4.86 ; p<0.05\right]$} \\
\hline Do I trust my doctor? & $f=108 ; 92.30 \%$ & $f=116 ; 99.10 \%$ & {$\left[x^{2}(2)=6.69 ; p<0.05\right]$} \\
\hline Does my doctor understand me? & $f=108 ; 92.30 \%$ & $f=116 ; 99.10 \%$ & {$\left[x^{2}(2)=6.69 ; p<0.05\right]$} \\
\hline $\begin{array}{l}\text { Does my doctor continue taking } \\
\text { care of me? }\end{array}$ & $f=116 ; 99.10 \%$ & $f=111 ; 94.90 \%$ & {$\left[x^{2}(2)=3.68 ; p<0.05\right]$} \\
\hline $\begin{array}{l}\text { Am I satisfied with the } \\
\text { communication with my doctor? }\end{array}$ & $f=105 ; 89.70 \%$ & $f=115 ; 98.30 \%$ & {$\left[x^{2}(2)=7.60 ; p<0.05\right]$} \\
\hline
\end{tabular}

The sum of positive evaluations based on clinical and sociodemographic data were also compared. However, no statistically significant differences were found between groups: by type of care $(\mathrm{U}=6794.000 ; \mathrm{p}>0.001)$, sex $(\mathrm{U}=6738.000 ; \mathrm{p}$ $>0.001)$, marital status $\left[X^{2}(3)=0.607 ; \mathrm{p}>0.001\right]$, education $\left[X^{2}(6)=5.99 ; \mathrm{p}>\right.$ $0.001]$, religion $\left[X^{2}(2)=1.55 ; \mathrm{p}>0.001\right]$, presence of work activity $(\mathrm{U}=3820.500$; $\mathrm{p}>0.001)$, presence of leisure activity $(\mathrm{U}=5211.500 ; \mathrm{p}>0.001)$, and presence of support network $(U=1102.500 ; p>0.001)$.

\section{Discussion}

It was observed that most patients believed they had a good relationship with their doctors. They believed that the professionals show accessibility, attention, care, understanding, trust and good communication. These are crucial factors for patients, who expect from their doctors availability, cordiality, empathy, listening, attention, good communication and solidarity towards their suffering ${ }^{(26)}$.

These data may indicate that patients tend to over-evaluate their doctors. They trust the professional's guidelines and barely resist paternalism when this is present ${ }^{(6)}$. This occurs especially in oncology, where the patients seem to create greater expectations about their relationship with the doctor than with other health professionals ${ }^{(15)}$. They are fragile, in need of care, and see their doctor as someone who can cure or alleviate their suffering, as someone who understand and support them in this moment of adversity. With that, it is recognized that the relationship between professional and patient can be influenced by the place and context of care ${ }^{(16)}$.

Another aspect that may have influenced these data is the profile of the participants, who were users of public hospitals in Ceará. They are people who generally have a low level of education, are disempowered with respect to their therapeutic process, and see themselves more in the condition of submission to doctors, with an attitude of confirmism, a though that public health services are "better than nothing"(29). These are factors that may have contributed for responses qualified as good.

On the other hand, it can be inferred that doctors adopt a more comprehensive and humanized perspective of care with patients in the process of dying, discarding the 
limited and exclusively curative perspective typical of the paternalistic character ${ }^{(9)}$. This way of relating from care enhances the subject's autonomy and freedom in the face of his illness ${ }^{15}$ and benefits from its subjectivity in broadening the understanding of the process ${ }^{(20)}$.

It was also found that patients in palliative care made more positive evaluations than patients experiencing dysthanasia. It can be inferred that doctors in the palliative care team develop a better relationship with their patients than doctors in curative care. This reinforces the guidelines for palliative care, in which the focus is on the sick person, and not on his illness, giving attention to his whole biopsychosocial condition $^{(20)}$.

Contact and communication are fundamental technologies for a good professionalpatient relationship, as they promote security and certainty of care for the patient ${ }^{(9,27)}$. They must be characterized by honesty, without conspiracy of silence ${ }^{(15)}$. Studies show that trust is the primary item in the relationship between doctors and patients in palliative care ${ }^{(15)}$. For such, the attitudes that are most associated with greater trust in doctors, besides technical competence, are: demonstration of attention and care and quality of communication. These are aspects that prevail among palliative care doctors, and that is why there must be a focus on the communication training of medical students and doctors ${ }^{(26)}$.

In addition, palliative care requires autonomy in the relationship between health professionals and patients. The latter are regarded as the protagonists of the process. They are the ones who define their desire and limits, and they participate in the decision-making about their therapeutic plan. Health professionals are not the only holders of knowledge, but have an important role: sharing of care and provision of comprehensive care for the subject who is dying ${ }^{(15)}$.

On the other hand, patients experiencing dysthanasia made better evaluations in terms of number of visits and continuity of care than patients in palliative care. It is inferred that a limitation in the daily presence of palliative care physicians occurs due to the small number of palliative care teams in hospitals. Brazil has more than 5,000 hospitals and only about 131 provide palliation, usually with only one palliative care physician for the entire hospital ${ }^{(23)}$. This is due to the lack of investment and the limited number of professionals specialized in this area and prepared for this type of assistance, which are factors tha compromising the effectiveness of this type of care $^{(22)}$. Consequently, the proportion of number of patients to number of doctor is much higher in palliation than in curative approaches, and a limitation to the doctors' capacity to make daily visits to all patients.

Finally, the best evaluation of continuity of care among patients experiencing dysthanasia can be understood from two perspectives. As explained earlier, there is a small number of palliative care teams in the country ${ }^{(23)}$, which can generate a lesser amount of visits and less presence of doctors and a lesser impression of care. In addition, there is still a culture marked by a strong dichotomy between healing and caring that can generate in the patient a false belief that, if he is not being cured, he is not being cared for. On this aspect, it is noteworthy that palliative care is supported by orthothanasia, based on the recognition of death as a natural process, which must not be delayed or accelerated, and that both patients and their families must receive comprehensive care ${ }^{(21)}$. This process cannot be confused with mistanasia, known as social euthanasia, in which there is the abandonment of the patient ${ }^{(25)}$. However, the emphasis of the Brazilian health scenario on the cure, with a focus on 
the disease, mitigates the recognition of the importance of care actions focused on the subject ${ }^{(20)}$. Therefore, it is important to remember the broader concept of health, which transcends the biological aspect and the cure, and recognizes the multiple determinants of health and care ${ }^{(8)}$. Health care, including palliative care, ratifies the need for the meeting between the health team, patient and family, all centered on a "living work", prioritizing the individual who experiences the illness, and not the disease or diagnosis ${ }^{(17,25)}$.

\section{Conclusions}

Based on the results and the analyses of this research, it is concluded that patients in palliative care attributed better scores to their doctors in terms of dedicated time, attention, confidence, understanding and communication. In contrast, patients experiencing dysthanasia made a better assessment of the frequency of visits and continuity of care. It is noteworthy that both groups made positive evaluations of the relationship with their doctors.

Like any scientific work, and although the results obtained are theoretically consistent and represent a significant contribution to the discussion on the relationship between doctors and patients in the process of dying, the present study has limitations. The main one has to do with the sample and its characteristics: (a) the collection was carried out only in the city of Fortaleza/CE, and thus the sample cannot be considered representative of the Brazilian population; and (b) the status performance was not used, which could contribute to the matching between patients in the two sample groups compared - palliative care and dysthanasia. Another limitation may be in the data collection. Even though this process was careful, some of the professionals who collected the data were psychologists of the hospital, and this may have generated social desirability and bias in the results.

Among the positive points of the study, the following can be mentioned: (a) interviews carried out based on the patients' perception, who are subjects still very silenced in research, and thus the present study gave them voice; (b) focus on the context of death, still little explored from the perspective of the doctor-patient relationship; (c) data collection in the Northeast region of Brazil, since most of the literature is concentrated on research carried out in other regions of the country; and (d) entry into a variety of hospitals in the region of Fortaleza, given the need to invest in research focusing on the quality of public health care.

The results of this study provide the readers with a deeper and more critical reflection on a topic that is distant from the majority of the population: the relationship between doctors and patients in the dying process. An attempt was made to unveil the therapeutic possibilities in patient care in the process of end of life, for a death with dignity. Doing so with cancer patients calls for new research to broaden the possibilities, with investigations conducted from the perspective of other social actors involved (patients' families, doctors and other professional categories) and in other contexts of diseases. Therefore, this research does not end here. This is also an invitation for the community, health professionals, experts, academics and managers to discuss, research and revise action plans to train medical students and health professionals to carry out interventions that prioritize the use of their oldest, simplest and most powerful technology: the relationship between professionals and patients. 


\section{References}

1. Costa TNM, Caldato MCF, Furlaneto IP. Percepção de formandos de medicina sobre a terminalidade da vida. Revista Bioética . 2019; 27: 661-73, dez. 2019. doi. 10.1590/198380422019274349

2. Merhy EE. Saúde: a cartografia do trabalho vivo. São Paulo: Hucitec, 2014.

3. Caprara A, Rodrigues J. A relação assimétrica médico-paciente: repensando o vínculo terapêutico. Ciência \& Saúde Coletiva 2004; 9: 139-46. doi: 10.1590/S141381232004000100014

4. Donabedian A. The quality of medical care. Science 1978; 200:856-64. doi: 10.1126/ science. 417400

5. Pazinatto MM. A relação médico-paciente na perspectiva da Recomendação CFM 1/2016. Revista Bioética 2019; 27: 234-43. doi: 10.5935/2595-0118.20200005

6. Slavova-azmanova N, Newton JC, Hohnen H, Johnson CE, Saunders C. How communication between cancer patients and their specialists affect the quality and cost of cancer care. Support Care Cancer 2019; 27: 4575-85. doi: 10.1007/s00520-019-04761-w

7. Nicacio TR, Toledo VP, Garcia APRF. From alienation to the nursing clinic: care of patients with psychiatric comorbidity. Revista Brasileira de Enfermagem 2018; 71: 222936. doi: 10.1590/0034-7167-2017-0930.

8. Pessigatti BP, Rodrigues APC, Aguiar PV, Dias FM. Health biopsychosocial aspects of students and collaborators of a higher education institution suffering from headache. BrJP 2020; 3: 19-24. doi: 10.5935/2595-0118.20200005.

9. Campos VF, Silva JM, Silva JJ. Comunicação em cuidados paliativos: equipe, paciente e família. Revista Bioética 2019; 27: 711-8. doi: 10.1590/1983-80422019274354

10. Probst MA, Noseworthy PA, Brito JP, Hess EP. Shared decision-making as the future of emergency cardiology. Can J Cardiol 2018; 34: 117-24. doi: 10.1016/j.cjca.2017.09.014

11. Kovács MJ. Educação para a morte. Psicologia: Ciência e Profissão 2005; 25: 484-97. doi: 10.1590/s1414-98932005000300012.

12. Arruda LM, Abreu KPB, Santana LBC, Sales MVC. Variables that influence the medical decision regarding Advance Directives and their impact on end-of-life care. Einstein (São Paulo) 2020; 18: eRW4852. doi: /10.31744/einstein_journal/2020rw4852.

13. Pessini L. Vida e morte na UTI: a ética no fio da navalha. Revista Bioética . 2016; 24 : 54-63. doi: 10.1590/1983-80422016241106.

14. Cassel EJ. The nature of suffering and the goals of medicine. N Engl Med 1982; 306: 639-45. doi: 10.1056/NEJM198203183061104

15. Bastos LOA, Andrade EM, Andrade EO. Relação médico-paciente na oncologia: estudo a partir da perspectiva do paciente. Rev Bioét 2017; 25: 563-76. doi: /10.1590/198380422017253213.

16. Souza YV, Gomes RS, Sá BVS, Mattos RMPR, Pimentel DMM. Percepção de pacientes sobre sua relação com médicos. Revista Bioét 2020; 28: 332-43. doi: 10.1590/198380422020282395.

17. Merhy EE. Um ensaio sobre o médico e suas valises tecnológicas: contribuições para compreender as reestruturações produtivas do setor saúde. Interface Comun Saúde Educ 2000; 4: 109-16. doi: /10.1590/S1414-32832000000100009

18. Saunders DC. Into the valley of the shadow of death: a personal therapeutic journey. BMJ 1996; 313: 1599-601.

19. Saunders DC. Hospice and palliative care: an interdisciplinary approach. London: Edward Arnold, 1990. 
20. Rosas-Jiménez CA, Díaz-Díaz Á. La escucha: elemento fundamental en la atencion espiritual del cuidado paliativo. Persona y Bioética 2017; 21: 280-91. doi: 10.5294/ pebi.2017.21.2.8

21. World Health Organization [WHO]. Definition of Palliative Care; 2018 [Acesso 17 julio 2020]. Disponible en: http://www.who.int/cancer/palliative/definition/en

22. Radbruch L, Lima L, Knaul F, Wenk R, Ali Z, Bhatnaghar S, et al. Redefining Palliative care - a new consensus-based definition. J Pain Symptom Manage 2020; 59: 965-1164. doi: 10.1016/j.jpainsymman.2020.04.027

23. Academia Nacional de Cuidados Paliativos (ANCP). Panorama dos Cuidados Paliativos no Brasil. São Paulo: ANCP, 2018 [Acceso 20 agosto 2020]. Disponível em: https:// paliativo.org.br/wp-content/uploads/2018/10/Panorama-dos-Cuidados-Paliativos-noBrasil-2018.pdf

24.Zimmermann C, Swami N, Krzyzanowska M, Leighl N, Rydall A, Rodin G, et al. Perceptions of palliative care among patients with advanced cancer and their caregivers. Can Med Assoc J 2016; 188: 217-7. doi: /10.1503/cmaj.151171

25. Almeida HRA, Melo CF. Ortotanasia y muerte digna en pacientes con cáncer: la percepción de los profesionales de la salud. Psicooncología 2019; 16: 143-60. doi: $10.5209 /$ psic. 61442

26. Bartholomäus M, Zomorodbakhsch B, Micke O, Prott FJ, Rudolph I, Seilacher E, et al. Cancer patients' needs for virtues and physicians' characteristics in physician-patient communication: a survey among patient representatives. Support Care Cancer 2019; 27: 2783-88. doi: 10.1007/s00520-018-4585-3

27. Freiberger MH, Carvalho D, Bonamigo EL. Comunicação de más notícias a pacientes na perspectiva de estudantes de medicina. Revista Bioét 2019; 27: 318-25. doi: 10.1590/198380422019272316

28. Conselho Federal de Medicina (CFM). Nível de evidência científica por tipo de estudo; 2018 [Acesso 17 jul 2020]. Disponível em: http://www.portalmedico.org.br/ diretrizes/100_diretrizes/Texto_Introdutorio.pdf

29. Melo CF, Alchieri JC, Magalhães BJ, Araújo Neto JL. Avaliação da Estratégia Saúde da Família em Natal a partir das crenças dos seus usuários Evaluation of Family Health Strategy in Natal from the beliefs of its users. Revista de Pesquisa: Cuidado é Fundamental Online. 2017; 9: 620-26. doi: 10.9789/2175-5361.2017.v9i3.620-626.

30. Feltz-Cornelis CMD, Van Oppen P, Van Marwijk HW, Beurs E, Van Dyck R. A patient-doctor relationship questionnaire (PDRQ-9) in primary care: development and psychometric evaluation. Gen Hosp Psychiatry 2004; 26: 115-20. doi: /10.1016/j. genhosppsych.2003.08.010 